\title{
Clinical Variability of SYNJ1-Associated Early-Onset Parkinsonism
}

OPEN ACCESS

Edited by:

Ignacio Mata

Cleveland Clinic, United States

Reviewed by:

Coro Paisan-Ruiz,

Icahn School of Medicine at Mount

Sinai, United States

Anna De Rosa,

Università di Napoli Federico II, Italy Marina Picillo,

University of Salerno, Italy

${ }^{*}$ Correspondence:

Suzanne Lesage

suzanne.lesage@upmc.fr

${ }^{\dagger}$ See Supplementary Information for a full list of members of the PDG group

Specialty section:

This article was submitted to

Neurogenetics,

a section of the journal

Frontiers in Neurology

Received: 31 December 2020 Accepted: 25 February 2021

Published: 25 March 2021

Citation:

Lesage S, Mangone G, Tesson C,

Bertrand $H$, Benmahdjoub $M$, Kesraoui S, Arezki M, Singleton A, Corvol J-C and Brice A (2021) Clinical Variability of SYNJ1-Associated

Early-Onset Parkinsonism.

Front. Neurol. 12:648457.

doi: 10.3389/fneur.2021.648457
Suzanne Lesage ${ }^{1 *}$, Graziella Mangone ${ }^{1}$, Christelle Tesson ${ }^{1}$, Hélène Bertrand ${ }^{1}$, Mustapha Benmahdjoub ${ }^{2}$, Selma Kesraoui ${ }^{2}$, Mohamed Arezki ${ }^{2}$, Andrew Singleton ${ }^{3}$, Jean-Christophe Corvol ${ }^{1}$ and Alexis Brice ${ }^{1}$ on behalf of the French Parkinson disease Genetics Study Group (PDG) ${ }^{\dagger}$

${ }^{1}$ Sorbonne Université, Institut du Cerveau-Paris Brain Institute-ICM, INSERM, CNRS, Assistance Publique Hôpitaux de Paris, Hôpital Pitié-Salpêtrière, CIC Neurosciences, Paris, France, ${ }^{2}$ Frantz Fanon Hospital, CHU Blida, Blida, Algeria,

${ }^{3}$ Laboratory of Neurogenetics, National Institute on Aging, National Institutes of Health, Bethesda, MD, United States

Autosomal recessive early-onset parkinsonism is clinically and genetically heterogeneous. Mutations of three genes, PRKN, PINK1, and DJ-1 cause pure phenotypes usually characterized by levodopa-responsive Parkinson's disease. By contrast, mutations of other genes, including ATP13A2, PLA2G6, FBXO7, DNAJC6, SYNJ1, VPS13C, and PTRHD1, cause rarer, more severe diseases with a poor response to levodopa, generally with additional atypical features. We performed data mining on a gene panel or whole-exome sequencing in 460 index cases with early-onset ( $\leq 40$ years) Parkinson's disease, including 57 with autosomal recessive disease and 403 isolated cases. We identified two isolated cases carrying biallelic mutations of SYNJ1 (double-heterozygous p.D791fs/p.Y232H and homozygous p. Y832C mutations) and two siblings with the recurrent homozygous p.R258Q mutation. All four variants were absent or rare in the Genome Aggregation Database, were predicted to be deleterious on in silico analysis and were found to be highly conserved between species. The patient with both the previously unknown p.D791fs and p.Y232H mutations presented with dystonia-parkinsonism accompanied by a frontal syndrome and oculomotor disturbances at the age of 39. In addition, two siblings from an Algerian consanguineous family carried the homozygous p.R258Q mutation and presented generalized tonic-clonic seizures during childhood, with severe intellectual disability, followed by progressive parkinsonism during their teens. By contrast, the isolated patient with the homozygous p. Y832C mutation, diagnosed at the age of 20 , had typical parkinsonism, with no atypical symptoms and slow disease progression. Our findings expand the mutational spectrum and phenotypic profile of SYNJ1-related parkinsonism.

Keywords: Parkinson's disease, SYNJ1, autosomal recessive inheritance, early-onset parkinsonism, atypical Parkinson's disease 


\section{INTRODUCTION}

Parkinson's disease (PD), the second most frequent neurodegenerative disorder after Alzheimer's disease, affects about $2 \%$ of people over the age of 60 years. PD affects dopaminergic neurons in the substantia nigra, causing characteristic motor signs, such as bradykinesia, rigidity with resting tremor and postural instability; it also affects other brain areas, causing non-motor signs, such as olfactory dysfunction, cognitive impairment, psychiatric symptoms and autonomic dysfunction (1). PD is monogenic and caused by rare, highly penetrant mutations in $10-15 \%$ of $\mathrm{PD}$ patients, but most PD cases are sporadic and probably due to a combination of environmental, genetic and epigenetic factors. The last 25 years have seen great progress toward understanding the genetic basis of this disease, with the identification of disease-causing genes. At least 23 loci and 13 genes clearly linked to inherited forms of parkinsonism have been identified, including 10 causing early-onset (EO) autosomal recessive (AR) forms (PRKN, PINK1, DJ-1, ATP13A2, PLA2G6, FBXO7, DNAJC6, SYNJ1, VPS13C, and PTRHD1) [reviewed in Lunati et al. (2)]. AR EO PD is clinically and genetically heterogeneous: it is most frequently caused by PRKN, PINK1 and DJ-1 mutations, particularly in patients with a positive family history and/or consanguinity, with phenotypes resembling typical levodopa-responsive EO PD and slow disease progression. However, rare mutations of ATP13A2, PLA2G6, FBXO7, DNAJC6, SYNJ1, VPS13C, and PTRHD1 cause more severe disease with additional neurological signs and symptoms, such as cognitive decline, dystonia, epilepsy, pyramidal features, and a less consistent response to levodopa [reviewed in Lunati et al. (2)].

Synaptojanin 1, encoded by SYNJ1 on chromosome 21q22.11, was first identified in 1994 as a brain-specific $145 \mathrm{kDa}$ protein highly conserved throughout evolution (3). It seems to be involved in synaptic vesicle endocytosis and recycling $(4,5)$. Biallelic mutations of SYNJ1 are associated with two distinct phenotypes: EO PD (PARK20) and a severe neurodegenerative disorder with intractable seizures and tauopathies (6-20). Patients with SYNJ1 mutations therefore display highly variable phenotypes.

We performed data mining on a gene panel or whole-exome sequencing in 460 index cases with EO PD. We identified biallelic SYNJ1 variants in a consanguineous family and two isolated cases of PD.

\section{MATERIALS AND METHODS}

In total, 460 index cases with $\mathrm{EO}[\leq 40$ years, mean age at onset (AAO): $33.1 \pm 6.9$ years] parkinsonism without mutations of genes known to cause PD and related disorders were analyzed for the presence of biallelic coding (small

Abbreviations: AAO, age at onset; AR, autosomal recessive; CADD, combined annotation-dependent depletion; EO, early-onset; GnomAD, Genome Aggregation Database; MMSE, Mini Mental State Examination; MRI, magnetic resonance imaging; NGS, next-generation sequencing; PD, Parkinson's disease; UPDRS-III, Unified Parkinson's Disease Rating Scale part III. insertions/deletions, missense, and stop-gain changes) or splicesite ( \pm 5 base pairs from the coding exons or synonymous variants predicted to create splice defects) variants of SYNJ1. Index cases were recruited through the French network for the study of Parkinson's disease genetics (PDG group) and diverse collaborations with Mediterranean countries. There were 296 male and 164 female patients; most were Caucasian ( $n$ $=397,86.3 \%)$, and French $(n=314,79 \%)$, the others were North African ( $n=41,8.9 \%)$, or of other origins $(n=22)$. A family history of $\mathrm{PD}$, consistent with AR transmission, was reported in $12 \%$ of the index cases $(n=57), 403$ of the index cases were isolated cases with suspected consanguinity $(n=$ $16)$ or without consanguinity $(n=387)$. According to the clinical diagnostic criteria of the UK Parkinson Disease Society Brain Bank (21), most of the index cases $(n=431)$ had EO typical PD, the remaining 29 patients had EO parkinsonism with some atypical features (poor response to levodopa, pyramidal signs, oculomotor disturbances, or dementia). This study was approved by the appropriate institutional review boards, and written informed consent was obtained from all participants.

We investigated SYNJ1 mutations, by performing data mining on a customized next-generation sequencing (NGS) targeted gene panel containing 9-70 PD-associated genes, depending on the incremental version used (Supplementary Table 1), or whole-exome sequencing data obtained as previously described $(22,23)$ from a large cohort of patients with EO PD.

Sanger sequencing was used to confirm variants and cosegregation analyses, where possible.

\section{RESULTS}

\section{Genetic Findings}

We identified a familial case (FPD-1458-9) with the recurrent homozygous missense mutation, p.R258Q (c.773G $>$ A in exon 5) in SYNJ1 (GenBank accession number for the longer 1,612 amino acid isoform: NM_003895.3) and two isolated cases-one consanguineous patient (SPD-174-10) carrying a homozygous missense mutation (c.2495A $>\mathrm{G}$ in exon 19, p.Y832C) and another patient (SPD-68-1) carrying two heterozygous mutations (a missense variant, c.694T $>\mathrm{C}$ in exon 5, p.Y232H and a truncating deletion, c.2371delG in exon 18, p.D791Ifs*4) (Figure 1A). No additional family members were available for determining parental phase for these last two mutations. The index case, FPD-1458-9, came from a consanguineous family consisting of two healthy parents, two affected and five unaffected siblings.

All four mutations were verified by Sanger sequencing. Cosegregation analyses performed in the FPD-1458 family revealed that the proband's affected sister harbored the same homozygous p.R258Q mutation, whereas both the unaffected parents and one of the five unaffected siblings for whom DNA was available were heterozygous for this mutation (Figure 1A).

No other rare homozygous or biallelic deleterious variants of PD-associated genes were identified on gene panel or whole exome analyses, for any of the three index cases. 


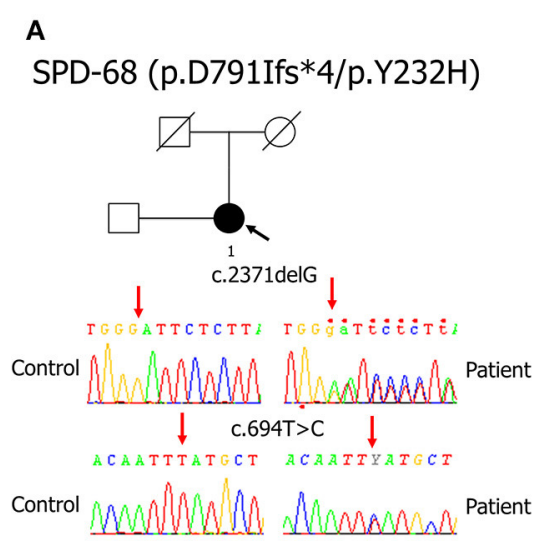

B

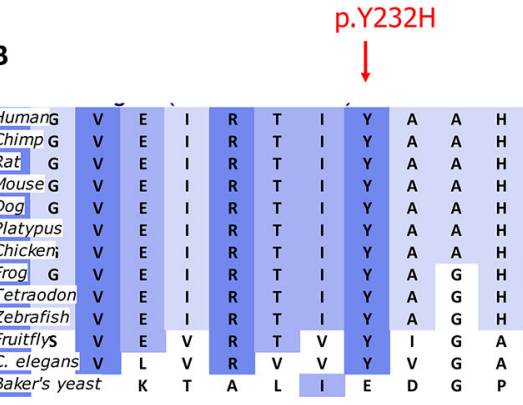

SPD-174 (p.Y832C)

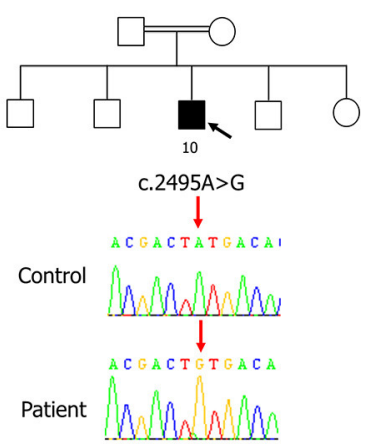

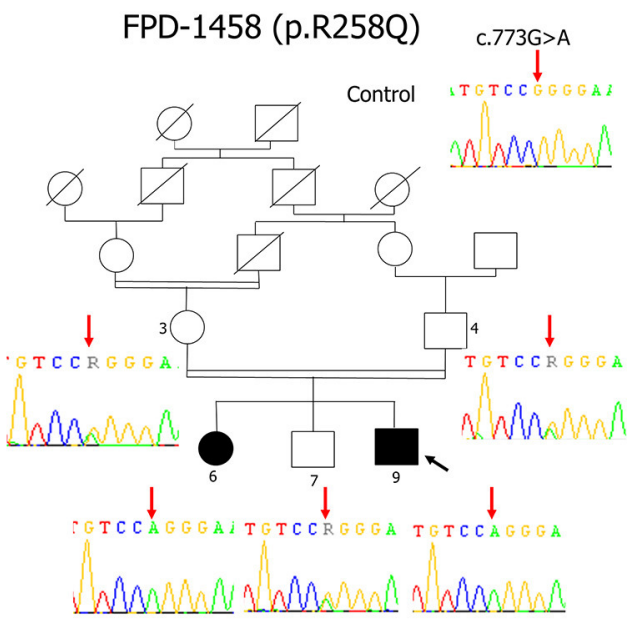

FIGURE 1 | (A) Pedigrees of the family and the two isolated cases with early-onset Parkinson's disease carrying SYNJ1 mutations. Affected family members are represented by black circles (female) or squares (male). The arrow indicates the index cases. Double lines indicate consanguineous parents. The corresponding Sanger sequence electrophoregrams are shown. The p.R258Q mutation segregated with the phenotype in the FPD-1458 family: the p.R258Q genotypes are highlighted by a red arrow (heterozygous state for individuals 3, 4, and 7 and homozygous for the two affected siblings, 6 and 9). (B) Evolutionary conservation of the regions of the p.Y232 amino-acid sequences (download from Alamut ${ }^{\circledR}$ Visual software, https://www.interactive-biosoftware.com/alamut-visual/). (C) Brain magnetic resonance imaging (MRI) for patient FPD-1458-9 showing the normal appearance of the various slices.

Both the SYNJ1 p.R258Q, and p.Y832C mutations were rare or absent from public databases and highly conserved between species $(6,7,10)$. By contrast, neither of the new SYNJ1 mutations, p.Y232H or p.D791Ifs*4, is present in any public database, including the Genome Aggregation Database (GnomAD). The missense variant p.Y232H is predicted to be pathogenic [SIFT: deleterious; Polyphen-2; probably damaging; MutationTaster: disease-causing; Align GVGD: Class C0 (GV: 122.78-GD: 0.00); combined annotation-dependent (CADD)_phred: 28] and has been shown to be conserved in orthologous sequences from C. elegans onwards (Alamut ${ }^{\circledR}$ Visual v.2.11 software, Interactive Biosoftware, Rouen, France) (Figure 1B). Both these mutations are located in functional domains: p.Y232H in the Sac1 domain and p.D791Ifs*4, in the 5 'phosphatase domain (Figure 2).

\section{Clinical Outcome}

\section{Case Report Family FPD-1458}

The two affected siblings were born to healthy first-cousin parents originating from Algeria.
The proband, FPD-1458-9, was a 25-year-old man who had suffered episodes of generalized tonic-clonic seizures at the age of 2 years after a bout of fever. These episodes were treated with sodium valproate and carbamazepine. The patient's psychomotor development was normal and he started school at the age of 6 years. Three years later, he presented a cognitive decline, leading to an interruption of his schooling. At the age of 20 years, the patient presented dysarthria, which was followed, 1 year later, by weakness of the muscles of the left arm and dystonic postures that were more marked distally and a progressive slowing of lower limb movements limiting the distance that the patient could walk. A few months later, a distal resting tremor appeared in the left upper limb, subsequently extending to the contralateral upper limb. Initial treatment with dopamine agonists was not tolerated. The patient was therefore given low doses of levodopa (50 mg), leading to a partial improvement of his motor symptoms, but rapidly resulting in disabling levodopa-induced dyskinesia. There was no evidence of autonomic dysfunction, other than urinary urgency. Clinical examination at the age of 25 years revealed a poorly cooperative 


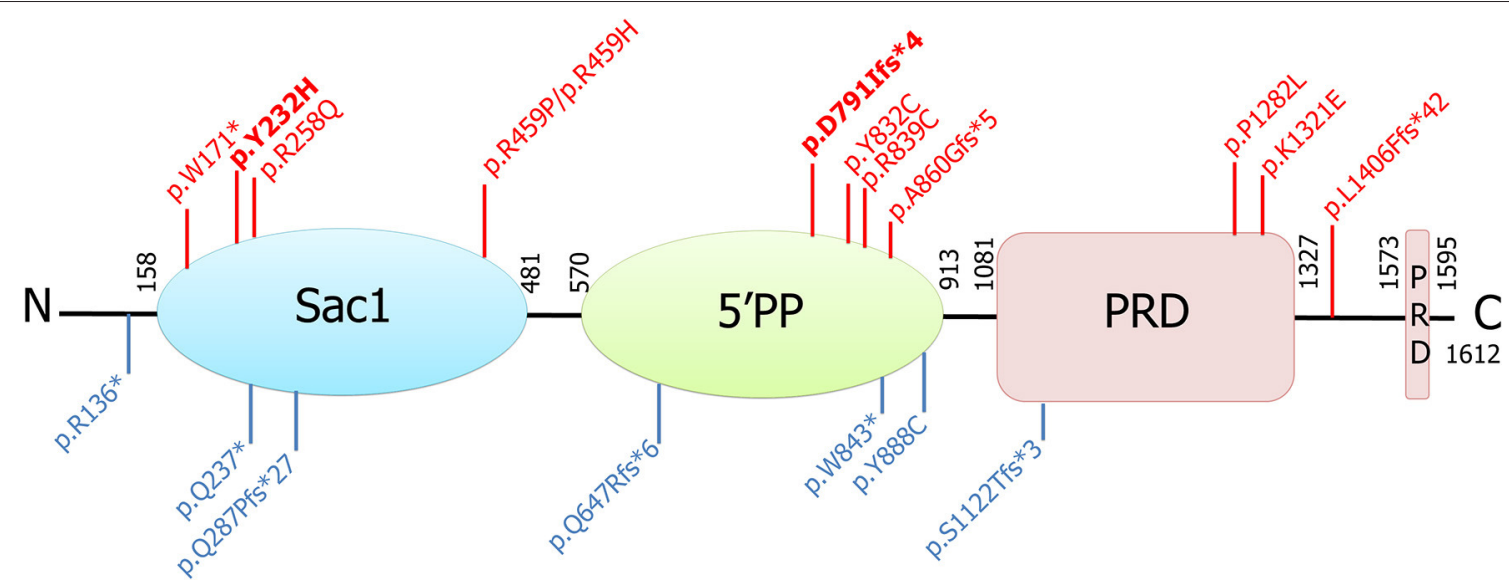

FIGURE 2 | Schematic representation of the longer isoform of the synaptojanin 1 protein, its functional domains, and all associated mutations identified to date. Those found in patients with parkinsonism are shown in red (in bold, those identified in this study), and those found in patients with intractable seizures and severe neurodegeneration are shown in blue. Sac1, suppressor of actin (Sac1-like inositol domain); 5'PP, inositol-5'-phosphatase domain; PRD, prolin-rich domain.

patient with parkinsonism combining an intermittent resting and postural tremor in both upper limbs, head tremor, bilateral but asymmetric plastic hypertonia with cogwheel rigidity on both sides, a global motor slowing and slowing of the gait, with a reduction of the swing of the arms predominantly on the left side, slight forward camptocormia, an inexhaustible nasopalpebral reflex, excessive drooling, but no oculomotor abnormalities or pyramidal signs. Off medication, the patient had a Unified Parkinson's disease rating scale part III (UPDRS-III) score of 35/108, and a Hoehn and Yahr stage of 2.5/5. The patient's cognitive disability made it impossible to perform a cognitive evaluation. Brain magnetic resonance imaging (MRI) results were normal (Figure 1C). An electroencephalogram (EEG) showed slow activity at $5 \mathrm{~Hz} / \mathrm{s}$, with no epileptic anomalies.

The patient's 31-year-old sister (FPD-1458-6) had treated generalized epilepsy, from the age of 14-20 years. Her psychomotor development was normal until the age of 10 years when she presented cognitive decline and was unable to continue her schooling. At the age of 26 years, she displayed progressive parkinsonism with dystonia, resting tremor and upper limb postural tremor predominantly on the left side, and progressive bradykinesia. Levodopa treatment, initiated at the age of 27 years, led to a significant improvement in clinical signs, but the patient developed early levodopa-induced dyskinesia, motor fluctuations, and end-of-dose dystonia. No autonomic dysfunction was observed. Neurological examination at the age of 29 years, on "off" medication, revealed a cooperating patient with parkinsonism characterized by resting tremor in the two upper limbs, predominantly on the left, plastic hypertonia, a loss of arm swing, slow gait and facial amimia, but no oculomotor abnormalities or pyramidal syndrome. The patient had a UPDRS-III motor score of 26/108 and a Hoehn and Yahr stage of $2 / 5$. It was not possible to perform a neuropsychological evaluation.

Other family members, including both unaffected parents and the five other unaffected siblings, displayed no signs or symptoms of epilepsy or parkinsonism.

\section{Isolated Case SPD-174-10}

Incomplete clinical information was obtained for patient SPD174-10, who was lost to follow-up. This 35-year-old man was born to consanguineous parents in Senegal. He presented an extrapyramidal akineto-rigid syndrome, at the age of 20. On neurological examination at the age of 35 years, a bilateral resting tremor was observed, with no other pyramidal signs or symptoms, cerebellar syndrome, apraxia, dystonia, or oculomotor disturbances. During the "on" stage, this patient had a Hoehn and Yahr stage of 5/5 after 16 years of disease progression. No specific treatment or response to treatment was recorded, but the patient developed urinary incontinence and erectile dysfunction. No neuropsychological evaluation or brain MRI scan was recorded at his last examination.

\section{Isolated Case SPD-68-1}

Patient SPD-68-1 was a 61-year-old French woman, with no family history of PD or known parental consanguinity. She developed micrography, slow gait and a chin tremor at the age of 39, rapidly followed by facial and cervical dystonia. Parkinsonism was diagnosed at the age of 43. Akinesia and rigidity responded to levodopa ( $100 \mathrm{mg}, 3$ times/day), but with the immediate development of motor fluctuations and disabling dyskinesias. One year later, the patient presented a bilateral, asymmetric, levodopa-responsive (50\%) extrapyramidal syndrome (left > right): akinesia and rigidity but no resting tremor, motor fluctuations with diphasic (facial and lower limb dystonia) and peak-dose choreic dyskinesia (oromandibular, right upper limb), permanent posterior cervical dystonia, vertical gaze palsy, freezing of gait when "off" levodopa, but no postural instability, moderate dysarthria and hypophonia. A frontal syndrome was detected with perseverations and an applause sign [Mini-Mental State Examination (MMSE) score $=27 / 30]$. Deep tendon reflexes were brisk with no Babinski sign. There was no cerebellar dysfunction or dysautonomia. Brain computed tomography (CT) scan findings were normal. Gait freezing became more frequent, with the development of postural 
instability with falls 3 years after diagnosis, and a worsening of vertical gaze palsy and dysarthria. Levadopa sensitivity persisted (70\% improvement following levodopa challenge, 9 years after diagnosis), but motor fluctuations and dyskinesias (diphasic and peak-dose) worsened. A moderate worsening of the frontal syndrome was observed, but instrumental functions were preserved [Mattis Dementia Rating Scale (MDRS) = 134/144 and MMSE score $=21 / 30,9$ years after diagnosis]. Eighteen years after diagnosis, this patient had severe dysarthria and mild dysphagia on medication.

\section{DISCUSSION}

SYNJ1-related diseases are heterogeneous in terms of their symptoms, ranging from EO typical PD (10) to EO complex parkinsonism (6-8, 10-16) (both designated PARK20), and severe neurodegeneration with intractable seizures (17-20) (Table 1).

We report here the molecular and associated clinical findings for two familial cases with the recurrent homozygous p.R258Q mutation and two apparently sporadic cases, each carrying, either double-heterozygous of new p.D791fs/p.Y232H variants or the known homozygous $\mathrm{p}$. Y832C mutation.

Two independent groups initially reported the presence of the same SYNJ1 p.R258Q missense mutation in the homozygous state in two consanguineous sib-pairs of Sicilian and Iranian origin $(6,7)$. A third family from Naples, was subsequently found to have the same recurrent SYNJ1 mutation in two non-consanguineous siblings (8). Previous haplotype analyses in the two Italian families did not support the hypothesis of a common founder for the p.R258Q variant (8), instead suggesting a possible mutational hotspot. An additional nonconsanguineous family of German origin was found to carry this mutation in the heterozygous state, together with a nonsense mutation at a trans location (Table 1). We report here the identification of a fourth consanguineous family of Algerian origin with the homozygous p.R258Q mutation. These families were characterized by EO atypical parkinsonism, with an onset in the third decade of life, with rapid progression through the initial stages and a stabilization of the disease at later stages (24). The principal clinical features of parkinsonian disease in these patients were a combination of tremor, dystonia, bradykinesia, and, a poor response to levodopa treatment in all but our case. Additional atypical signs, such as seizures, cognitive impairment, developmental delay, and oculomotor disturbances, were variable. Indeed, our siblings presented generalized tonicclonic seizures, as seen in the Iranian siblings, whereas the Neapolitan carriers suffered from episodes of clonic seizures. Unlike five of the other six p.R258Q carriers, our patients presented no oculomotor disturbances. Finally, mild or severe cognitive decline was observed in the Sicilian, Neapolitan and Algerian families, but not in the Iranian siblings. In both the German siblings harboring the p.R258Q variant in the compound heterozygous state, the principal clinical trait was early epilepsy followed by generalized dopa-responsive dystonia in infancy (13).
We also identified an isolated patient of Senegalese origin, from a consanguineous family, who harbored the same homozygous pY832C variant as recently reported in two Chinese consanguineous siblings with PD (10). Very little clinical information for this patient was collected at a single follow-up assessment, but the same typical parkinsonism was observed, with no atypical signs/symptoms.

Finally, we identified a non-consanguineous isolated case with two new heterozygous SYNJ1 variants, p.Y232H and p.D791Ifs*4, that may be pathogenic, based on the rarity of these variants and in silico analyses. We thus report a case extending the age at onset for SYNJ1 mutations carriers (39 years), identify, for the first time, SYNJ1 mutations in apparently isolated cases. However, the parental phase of these two variants is unknown, but the phenotype of this patient with two SYNJ1 mutations resembles that of the other PARK20 mutation carriers, who had atypical parkinsonism with earlyonset disease (at 20-31 years), a rapid development of dyskinesias on levodopa, predominantly axial symptoms with rapidly progressing gait impairment and falls, oculomotor disturbances and orofacial dystonia at onset (Table 1). Parkinsonism in our case was levodopa-responsive ( $>50 \%$ response after acute challenge and presence of motor fluctuations), as also reported in a few previous cases $(6,13,14)$ (Table 1), but the response was difficult to evaluate in the other six patients, due to severe dyskinesia and other adverse effects $(6,7,12)$. Unlike patients from most PARK20 families with atypical EO parkinsonism, this patient displayed no seizures. However, susceptibility to seizures varies considerably, even within families $(14,15)$. Seizures also occur in some patients with mutations of DNAJC6 (PARK19), encoding auxilin, which has been implicated in the uncoating of synaptic vesicles, potentially resulting in alterations to synaptic vesicle recycling (25). Like auxilin, synaptojanin 1 is involved in the postendocytic recycling of synaptic vesicles, providing additional support for the link between synaptic endosomal trafficking and PD. In addition, a link between seizures and the accumulation of tau protein has been suggested, based on the brain autopsy of a single patient with intractable epilepsy and a homozygous SYNJ1 truncating mutation showing tauimmunoreactive neurofibrillary degeneration in the substantia nigra (17).

Synaptojanin 1 is encoded by two open-reading frames (ORFs) of 170 and $145 \mathrm{kDa}$, encoding two major isoforms of 1,612 and 1,350 amino acids, respectively. The $145 \mathrm{kDa}$ ORF is strongly expressed in the brain, and the corresponding protein localizes to presynaptic nerve terminals (26). Both isoforms contain two consecutive phosphatase domains: an $\mathrm{N}$ terminal Sac1-like inositol domain and a central 5' -phosphatase domain followed by a C-terminal proline-rich domain (PRD). The longer $170 \mathrm{kDa}$ isoform contains an additional PRD. Interestingly, a single SYNJ1 mutation reported by Ben Romdhan et al. (14) is located in the C-terminal domain of the longer isoform.

In total 33 SYNJ1 mutation carriers originating from 19 families and isolated cases (13 with the PARK20-SYNJ1 phenotype and six with infancy treatment-resistant seizures 
TABLE 1 | Clinical features of patients with biallelic mutations of the SYNJ1 gene.

\begin{tabular}{|c|c|c|c|c|c|c|c|c|c|c|}
\hline & Patient & $\begin{array}{l}\text { SYNJ1 } \\
\text { mutations }\end{array}$ & Origin & Sex/AAE (y) & $\begin{array}{l}\text { Transmission/ } \\
\text { consanguinity }\end{array}$ & $\begin{array}{l}\text { Age at onset } \\
\text { of motor } \\
\text { symptoms (y) }\end{array}$ & Phenotype & $\begin{array}{l}\text { Seizures } \\
\text { (age at } \\
\text { onset) }\end{array}$ & $\begin{array}{l}\text { Response to } \\
\text { levodopa }\end{array}$ & Imaging data \\
\hline \multicolumn{11}{|c|}{ Early-onset typical or atypical parkinsonism } \\
\hline \multirow[t]{4}{*}{ Our study } & FPD-1458-9 & p.R258Q (hom) & Algeria & $M / 25$ & AR/Yes & 20 & $\begin{array}{l}\text { Parkinsonism, dysarthria, dystonia, } \\
\text { drooling, postural instability, } \mathrm{Cl}\end{array}$ & Yes $(2$ y) & $\begin{array}{l}\text { Partial with } \\
\text { dyskinesia }\end{array}$ & Normal brain MRI \\
\hline & FPD-1458-6 & p.R258Q (hom) & Algeria & $F / 31$ & AR/Yes & 26 & Parkinsonism, dystonia, amimia, $\mathrm{Cl}$ & Yes (14 y) & $\begin{array}{l}\text { Good, with } \\
\text { adverse effects } \\
\text { (dyskinesia, } \\
\text { motor } \\
\text { fluctuations, } \\
\text { dystonia) }\end{array}$ & NA \\
\hline & SPD-174-10 & p.Y832C (hom) & Senegal & $M / 35$ & Spo/Yes & 20 & Parkinsonism & $\begin{array}{l}\text { No } \\
\text { information }\end{array}$ & Unknown & NA \\
\hline & SPD-68-1 & $\begin{array}{l}\text { p.Y232H/ } \\
\text { p.D791/fs*4\# } \\
\text { (double het) }\end{array}$ & France & $\mathrm{F} / 61$ & Spo/No & 39 & $\begin{array}{l}\text { Parkinsonism, facial and cervical } \\
\text { dystonia, vertical gaze palsy, } \\
\text { moderate dysarthria, hypophonia, } \\
\text { postural instability, brisk deep tendon } \\
\text { reflexes, MMSE 21/30 }\end{array}$ & No & $\begin{array}{l}\text { Good, with } \\
\text { adverse effects } \\
\text { (oromandibular } \\
\text { and limb } \\
\text { dystonias) }\end{array}$ & Normal brain CT scan \\
\hline \multirow[t]{2}{*}{ Krebs et al. (6) } & Patient I & p.R258Q (hom) & Iran & $M / 29$ & AR/yes & 20 & $\begin{array}{l}\text { Parkinsonism, eyelid apraxia and } \\
\text { dysarthria at the age of } 22 \text { years, } \\
\text { hypophonia, resting tremor, chin } \\
\text { tremor, postural instability, no } \mathrm{Cl}\end{array}$ & Yes (3 y) & $\begin{array}{l}\text { Not tolerated } \\
\text { (severe } \\
\text { dyskinesia) }\end{array}$ & $\begin{array}{l}\text { Mild cortical atrophy, } \\
\text { bilateral white matter } \\
\text { hyperintensity }\end{array}$ \\
\hline & Patient II & p.R258Q (hom) & Iran & $F / 39$ & AR/yes & Early twenties & $\begin{array}{l}\text { Parkinsonism, right hand tremor, } \\
\text { eyelid apraxia, severe jaw tremor, } \\
\text { anarthria, requiring assistance to walk } \\
\text { at the age of } 32 \text {, bedbound at } 37 \text {, } \\
\text { no } \mathrm{Cl}\end{array}$ & $\begin{array}{l}\text { Febrile } \\
\text { convulsion in } \\
\text { infancy }\end{array}$ & $\begin{array}{l}\text { Not tolerated } \\
\text { (severe } \\
\text { dyskinesia) }\end{array}$ & $\begin{array}{l}\text { Foramen magnum } \\
\text { meningioma at the age } \\
\text { of } 37\end{array}$ \\
\hline \multirow[t]{2}{*}{ Quadri et al. (7) } & NAPO-16 & p.R258Q (hom) & $\begin{array}{l}\text { Italy } \\
\text { (Sicily) }\end{array}$ & $\mathrm{M} / 47$ & AR/yes & 22 & $\begin{array}{l}\text { Parkinsonism, rest and action tremor, } \\
\text { dystonia in both hands, postural } \\
\text { instability, anarthria, severe dysarthria, } \\
\text { eyelid apraxia and supranuclear } \\
\text { vertical gaze palsy, dysphagia, Cl }\end{array}$ & No & $\begin{array}{l}\text { Not tolerated } \\
\text { (oromandibular } \\
\text { and limb } \\
\text { dystonias, } \\
\text { postural } \\
\text { hypotension) }\end{array}$ & $\begin{array}{l}\text { Diffuse cortex atrophy, } \\
\text { hyperintensity of } \\
\text { hippocampi, thinning } \\
\text { midbrain quadrigeminal } \\
\text { plate, nigrostriatal } \\
\text { dopaminergic deficit, } \\
\text { cortical } \\
\text { hypometabolism }\end{array}$ \\
\hline & NAPO-17 & p.R258Q (hom) & $\begin{array}{l}\text { Italy } \\
\text { (Sicily) }\end{array}$ & $F / 31$ & AR/yes & 28 & $\begin{array}{l}\text { Parkinsonism, rest and action tremor, } \\
\text { dystonia in the hands and feet, } \\
\text { dysarthria, dysphonia, mild } \\
\text { dysphagia, postural instability, } \\
\text { supranuclear vertical gaze palsy, brisk } \\
\text { deep tendon reflexes, Cl } \\
\text { (MMSE 26/30) }\end{array}$ & No & $\begin{array}{l}\text { Not tolerated } \\
\text { (oromandibular } \\
\text { and limb } \\
\text { dystonias, } \\
\text { postural } \\
\text { hypotension) }\end{array}$ & $\begin{array}{l}\text { Diffuse cortex atrophy, } \\
\text { hyperintensity of } \\
\text { hippocampi, thinning } \\
\text { midbrain quadrigeminal } \\
\text { plate, cortical } \\
\text { hypometabolism }\end{array}$ \\
\hline
\end{tabular}


TABLE 1 | Continued

\begin{tabular}{|c|c|c|c|c|c|c|c|c|c|c|}
\hline & Patient & $\begin{array}{l}\text { SYNJ1 } \\
\text { mutations }\end{array}$ & Origin & Sex/AAE (y) & $\begin{array}{l}\text { Transmission/ } \\
\text { consanguinity }\end{array}$ & $\begin{array}{l}\text { Age at onset } \\
\text { of motor } \\
\text { symptoms (y) }\end{array}$ & Phenotype & $\begin{array}{l}\text { Seizures } \\
\text { (age at } \\
\text { onset) }\end{array}$ & $\begin{array}{l}\text { Response to } \\
\text { levodopa }\end{array}$ & Imaging data \\
\hline \multirow[t]{2}{*}{ Olgiati et al. (8) } & NAPO-41 & p.R258Q (hom) & $\begin{array}{l}\text { Italy } \\
\text { (Naples) }\end{array}$ & $M / 31$ & AR/No & 28 & $\begin{array}{l}\text { Parkinsonism, hypomimia, } \\
\text { oromandibular tremor, trunk dystonia, } \\
\text { impaired speech, postural instability, } \\
\text { mild supranuclear vertical gaze } \\
\text { limitation, drooling, dysphagia at the } \\
\text { age of } 31, \text { MMSE 28/30 }\end{array}$ & $\begin{array}{l}\text { One episode } \\
\text { (uncertain) }\end{array}$ & Not treated & $\begin{array}{l}\text { No gross abnormalities, } \\
\text { normal brain MRI, } \\
\text { nigrostriatal } \\
\text { dopaminergic deficit, } \\
\text { mild bilateral } \\
\text { hypometabolism }\end{array}$ \\
\hline & NAPO-42 & p.R258Q (hom) & $\begin{array}{l}\text { Italy } \\
\text { (Naples) }\end{array}$ & $\mathrm{F} / 27$ & AR/No & 26 & $\begin{array}{l}\text { Parkinsonism, hypomimia, } \\
\text { oromandibular tremor, impaired } \\
\text { speech, brisk deep tendon reflexes, } \\
\text { MMSE } 25 / 30\end{array}$ & $\begin{array}{l}\text { One episode } \\
(16 \mathrm{y})\end{array}$ & Not treated & $\begin{array}{l}\text { No gross abnormalities, } \\
\text { normal brain MRI, } \\
\text { nigrostriatal } \\
\text { dopaminergic deficit, } \\
\text { mild bilateral } \\
\text { hypometabolism }\end{array}$ \\
\hline \multirow[t]{2}{*}{ Kirola et al. (12) } & $\mathrm{H} 1 \_1$ & p.R459P (hom) & India/M & $M / 32$ & AR/yes & 12 & $\begin{array}{l}\text { Parkinsonism, drooling, dystonia, } \\
\text { dysarthria, dysphagia, hypophonia, } \\
\text { intense constipation, falling } \\
\text { backwards, postural instability, no } \\
\text { dementia }\end{array}$ & $\begin{array}{l}\text { No } \\
\text { information }\end{array}$ & $\begin{array}{l}\text { Not tolerated } \\
\text { (dyskinesia and } \\
\text { dystonia) }\end{array}$ & $\begin{array}{l}\text { Hyperintensity in } \\
\text { substantia nigra }\end{array}$ \\
\hline & H1_2 & p.R459P (hom) & India/F & $F / 22$ & AR/yes & 18 & $\begin{array}{l}\text { Parkinsonism, drooling, dystonia, } \\
\text { dysathria, dysphagia, hypophonia, } \\
\text { falling backwards, constipation, no } \\
\text { dementia }\end{array}$ & $\begin{array}{l}\text { No } \\
\text { information }\end{array}$ & $\begin{array}{l}\text { Not tolerated } \\
\text { (dyskinesia and } \\
\text { dystonia) }\end{array}$ & NA \\
\hline \multirow[t]{2}{*}{$\begin{array}{l}\text { Rauschendorf } \\
\text { et al. (13) }\end{array}$} & Patient 1 & $\begin{array}{l}\text { p.W171*/ } \\
\text { p.R258Q } \\
\text { (compound het) }\end{array}$ & Germany & $\mathrm{M} / 21$ & $\mathrm{AR} / \mathrm{No}$ & 15 & $\begin{array}{l}\text { Generalized dystonia, Parkinsonism, } \\
\text { severe action tremor of the tongue, } \\
\text { head, and extremities, anarthria, } \mathrm{Cl}\end{array}$ & Yes (3-4 y) & $\begin{array}{l}\text { Excellent (with } \\
\text { L-dopa-induced } \\
\text { dyskinesia) }\end{array}$ & $\begin{array}{l}\text { Bilateral nigrostriatal } \\
\text { dopaminergic deficit, } \\
\text { bilateral caudate } \\
\text { hypometabolism }\end{array}$ \\
\hline & Patient 2 & $\begin{array}{l}\text { p.W171*/ } \\
\text { p.R258Q } \\
\text { (compound het) }\end{array}$ & Germany & $M / 32$ & AR/No & 13 & $\begin{array}{l}\text { Generalized dystonia, Parkinsonism, } \\
\text { action tremor of the upper } \\
\text { extremities, chin and tongue }\end{array}$ & $\begin{array}{l}\text { First days of } \\
\text { life }\end{array}$ & $\begin{array}{l}\text { Good (no } \\
\text { dyskinesia) }\end{array}$ & $\begin{array}{l}\text { Bilateral nigrostriatal } \\
\text { dopaminergic deficit, } \\
\text { bilateral caudate } \\
\text { hypometabolism }\end{array}$ \\
\hline \multirow[t]{2}{*}{$\begin{array}{l}\text { Taghavi et al. } \\
\text { (15) }\end{array}$} & F22P1 & p.R839C (hom) & Iran & $\mathrm{M} / 30$ & AR/Yes & 24 & $\begin{array}{l}\text { Parkinsonism, chin tremor, dysarthria, } \\
\text { longitudinally fissured tongue, } \\
\text { postural instability }\end{array}$ & Yes (24 y) & Poor & NA \\
\hline & F22P2 & p.R839C (hom) & Iran & $\mathrm{F} / 47$ & AR/Yes & 27 & Parkinsonism, postural instability & No & Poor & NA \\
\hline \multirow[t]{2}{*}{$\begin{array}{l}\text { Ben Romdhan } \\
\text { et al. (14) }\end{array}$} & PD1 & $\begin{array}{l}\text { p.L1406Ffs*42/ } \\
\text { p.K1321E } \\
\text { (compound het) }\end{array}$ & Tunisia & $\mathrm{M} / 23$ & AR/Yes & 16 & $\begin{array}{l}\text { Parkinsonism, postural instability } \\
\text { dystonia in the left arm, dysarthria, } \\
\text { moderate } \mathrm{Cl} \text { (MMSE 20/30) }\end{array}$ & Yes $(7 \mathrm{y})$ & $\begin{array}{l}\text { Good (no } \\
\text { dyskinesia) }\end{array}$ & Normal brain MRI \\
\hline & PD2 & $\begin{array}{l}\text { p.L1406Ffs*42/ } \\
\text { p.K1321E } \\
\text { (compound het) }\end{array}$ & Tunisia & $F / 24$ & AR/Yes & 21 & $\begin{array}{l}\text { Parkinsonism, postural instability, } \\
\text { supranuclear vertical gaze palsy, } \\
\text { moderate } \mathrm{Cl} \text { (MMSE 21/30) }\end{array}$ & No & $\begin{array}{l}\text { Good (no motor } \\
\text { complications) }\end{array}$ & Normal brain MRI \\
\hline Hong et al. (16) & $\| 1$ & $\begin{array}{l}\text { p.A860Gfs*5/ } \\
\text { p.P1282L } \\
\text { (compound het) }\end{array}$ & China & $F / 35$ & $\mathrm{AR} / \mathrm{No}$ & 31 & $\begin{array}{l}\text { Parkinsonism, mild dysarthria, } \\
\text { diplopia, dystonia, MMSE 28/30 }\end{array}$ & $\begin{array}{l}\text { No } \\
\text { information }\end{array}$ & Poor & Mild cortical atrophy \\
\hline
\end{tabular}


TABLE 1 | Continued

\begin{tabular}{|c|c|c|c|c|c|c|c|c|c|c|}
\hline & Patient & $\begin{array}{l}\text { SYNJ1 } \\
\text { mutations }\end{array}$ & Origin & Sex/AAE (y) & $\begin{array}{l}\text { Transmission/ } \\
\text { consanguinity }\end{array}$ & $\begin{array}{l}\text { Age at onset } \\
\text { of motor } \\
\text { symptoms (y) }\end{array}$ & Phenotype & $\begin{array}{l}\text { Seizures } \\
\text { (age at } \\
\text { onset) }\end{array}$ & $\begin{array}{l}\text { Response to } \\
\text { levodopa }\end{array}$ & Imaging data \\
\hline & $\| 3$ & $\begin{array}{l}\text { p.A860Gfs*5/ } \\
\text { p.P1282L } \\
\text { (compound het) }\end{array}$ & China & $\mathrm{M} / 30$ & AR/No & 28 & $\begin{array}{l}\text { Parkinsonism, diplopia, dystonia, } \\
\text { MMSE 29/30 }\end{array}$ & $\begin{array}{l}\text { No } \\
\text { information }\end{array}$ & Poor & Normal brain MRI \\
\hline \multirow[t]{2}{*}{ Xie et al. (10) } & Patient 1 & p.Y832C (hom) & China & $F / 52$ & AR/Yes & 40 & Parkinsonism, MMSE 30/30 & No & Good & NA \\
\hline & Patient 2 & p.Y832C (hom) & China & $\mathrm{M} / 54$ & AR/Yes & 52 & Parkinsonism & No & $\begin{array}{l}\text { Not prescribed } \\
\text { levodopa }\end{array}$ & NA \\
\hline $\begin{array}{l}\text { Kumar et al. } \\
\text { (11) }\end{array}$ & 114 & p.R459H (hom) & India & $\begin{array}{l}\text { No } \\
\text { information }\end{array}$ & No information & 34 & Parkinsonism with poor information & $\begin{array}{l}\text { No } \\
\text { information }\end{array}$ & Unknown & NA \\
\hline \multicolumn{11}{|c|}{ Early-onset treatment-resistant seizures and severe neurodegenerative decline } \\
\hline $\begin{array}{l}\text { Dyment et al. } \\
\text { (17) }\end{array}$ & 1 & p.R136* (hom) & Pakistan & $\begin{array}{l}\mathrm{M} / \text { died at } \\
6.5 \text { years of } \\
\text { age }\end{array}$ & Spo/Yes & NA & $\begin{array}{l}\text { No parkinsonism, progressive } \\
\text { neurodegenerative course, feeding } \\
\text { intolerance at age of } 1 \text { year, and } G \\
\text { tube dependence at the age of } 2 \\
\text { years, hypotonia progressing to } \\
\text { multiple contractures, no vocalization, } \\
\text { cortical blindness }\end{array}$ & Yes $(9 \mathrm{~d})$ & Unknown & $\begin{array}{l}\text { Brain MRI: mild } \\
\text { cerebral atrophy at the } \\
\text { age of } 5 \text { years }\end{array}$ \\
\hline \multirow[t]{5}{*}{$\begin{array}{l}\text { Hardies et al. } \\
\text { (18) }\end{array}$} & Family $\mathrm{A} / 1$ & p.Y888C (hom) & Morocco & $\mathrm{F} / 7$ & AR/Yes & NA & $\begin{array}{l}\text { No parkinsonism, progressive } \\
\text { neurodegenerative course, feeding } \\
\text { problems, hypotonia progressing to } \\
\text { spastic tetraplegia, central visual } \\
\text { impairment, severe intellectual } \\
\text { disability }\end{array}$ & Yes $(2.5 \mathrm{~m})$ & Unknown & Normal brain MRI \\
\hline & Family A/2 & p.Y888C (hom) & Morocco & $\mathrm{M} / 6$ & AR/Yes & NA & $\begin{array}{l}\text { No parkinsonism, progressive } \\
\text { neurodegenerative course, feeding } \\
\text { problems, hypotonia progressing to } \\
\text { spastic tetraplegia, central visual } \\
\text { impairment, severe intellectual } \\
\text { disability }\end{array}$ & Yes $(6 \mathrm{~m})$ & Unknown & Normal brain MRI \\
\hline & Family B/1 & p.W843* (hom) & Morocco & $\mathrm{F} / 5$ & AR/Yes & NA & $\begin{array}{l}\text { No parkinsonism, profound } \\
\text { intellectual disability, progressive } \\
\text { spastic tetraplegia, feeding problems } \\
\text { with gastrostomy }\end{array}$ & Yes (1 d) & Unknown & Normal brain MRI \\
\hline & Family B/2 & p.W843* (hom) & Morocco & $F / 2.5$ & AR/Yes & NA & $\begin{array}{l}\text { No parkinsonism, profound } \\
\text { intellectual disability, progressive } \\
\text { spastic tetraplegia, feeding problems } \\
\text { with gastrostomy }\end{array}$ & Yes (1 d) & Unknown & Normal brain MRI \\
\hline & Family C/1 & $\begin{array}{l}\text { Q647Rfs*6/ } \\
\text { p.S1122Tfs³ } \\
\text { (compound het) }\end{array}$ & Caucasian & $\begin{array}{l}\mathrm{M} / \mathrm{died} \text { at } \\
\text { the age of } \\
2.5 \text { years }\end{array}$ & $\mathrm{AR} / \mathrm{No}$ & NA & $\begin{array}{l}\text { No parkinsonism, profound } \\
\text { intellectual disability, tube fed, } \\
\text { dystonia }\end{array}$ & Yes (12 d) & Unknown & $\begin{array}{l}\text { Normal brain MRI at } \\
\text { age } 6\end{array}$ \\
\hline
\end{tabular}


TABLE 1 | Continued

\begin{tabular}{|c|c|c|c|c|c|c|c|c|c|c|}
\hline & Patient & $\begin{array}{l}\text { SYNJ1 } \\
\text { mutations }\end{array}$ & Origin & Sex/AAE (y) & $\begin{array}{l}\text { Transmission/ } \\
\text { consanguinity }\end{array}$ & $\begin{array}{l}\text { Age at onset } \\
\text { of motor } \\
\text { symptoms (y) }\end{array}$ & Phenotype & $\begin{array}{l}\text { Seizures } \\
\text { (age at } \\
\text { onset) }\end{array}$ & $\begin{array}{l}\text { Response to } \\
\text { levodopa }\end{array}$ & Imaging data \\
\hline & Family C/2 & $\begin{array}{l}\text { Q647Rfs*6/ } \\
\text { p.S1122Tfs*3 } \\
\text { (compound het) }\end{array}$ & Caucasian & $\begin{array}{l}\mathrm{M} / \mathrm{died} \text { at } \\
\text { the age of } 8 \\
\text { years }\end{array}$ & AR/No & NA & $\begin{array}{l}\text { No parkinsonism, profound } \\
\text { intellectual disability, progressive } \\
\text { spastic tetraplegia, feeding problems } \\
\text { with gastrostomy }\end{array}$ & Yes (1 d) & Unknown & $\begin{array}{l}\text { Brain MRI: thin corpus } \\
\text { callosum and limited } \\
\text { gliosis and atrophy of } \\
\text { the periventricular white } \\
\text { matter }\end{array}$ \\
\hline \multirow[t]{2}{*}{$\begin{array}{l}\text { Al Zaabi et al. } \\
\text { (19) }\end{array}$} & Case 1 & p.Q237*(hom) & Oman & $F / 2$ & Spo/Yes & NA & $\begin{array}{l}\text { No parkinsonism, profound } \\
\text { intellectual disability, no feeding } \\
\text { difficulties, scoliosis, significant } \\
\text { truncal and peripheral hypotonia, and } \\
\text { persistent palmer and plantar reflexes }\end{array}$ & Yes (2 d) & Unknown & Normal brain MRI \\
\hline & Case 2 & p.Q237*(hom) & Oman & $M / 2$ & $\begin{array}{l}\text { First cousin of } \\
\text { case } 1 / \text { Yes }\end{array}$ & NA & $\begin{array}{l}\text { No parkinsonism, microcephaly at the } \\
\text { age of } 2 \text { years, profound intellectual } \\
\text { disability, feeding problems, } \\
\text { dysphagia and palatal insufficiency, } \\
\text { head lag and axial hypotonia with } \\
\text { hyperreflexia and clonus }\end{array}$ & Yes & Unknown & $\begin{array}{l}\text { Brain MRI: mild dilation } \\
\text { of the ventricles and } \\
\text { subarachnoid spaces }\end{array}$ \\
\hline $\begin{array}{l}\text { Samanta et al. } \\
\text { (20) }\end{array}$ & Patient 1 & $\begin{array}{l}\text { p.Q287Pfs } 27 \\
\text { (hom) }\end{array}$ & $\begin{array}{l}\text { Saudi } \\
\text { Arabia }\end{array}$ & $F / 2$ & Spo/Yes & NA & $\begin{array}{l}\text { No parkinsonism, profound } \\
\text { intellectual disability, profound } \\
\text { hypotonia, feeding problems, severe } \\
\text { cortical visual impairment, hypotonia } \\
\text { progressing to spastic tetraplegia, } \\
\text { brisk deep tendon reflexes, dystonia } \\
\text { of upper extremities }\end{array}$ & Yes (2 d) & Unknown & Normal brain MRI \\
\hline
\end{tabular}

AAE, age at last examination; AR, autosomal recessive; Cl, cognitive impairment; CT, computed tomography; d, day; F, female; het, heterozygote; hom, homozygote; M, male; MMSE, Mini-Mental State Examination; m, months; MRI, magnetic resonance imaging; NA, not available; Spo, sporadic; $y$, year.

"unknown parental phase. 
and severe neurodegenerative decline) were identified (Table 1). These last ten patients presented in the neonatal period with intractable seizures, hypotonia, feeding difficulties, and severe developmental delay but no parkinsonian signs/symptoms. These patients harbored six loss-of-function mutations (p.R136*, p.W843*, Q647Rfs*6, p.S1122Tfs*3, p.Q237*, p.Q287Pfs*27, Figure 2) in the homozygous or compound heterozygous state, shown in some cases to reduce the levels of the mutant transcript, whereas the homozygous missense mutant p.Y888C, affecting an amino acid located in the $5^{\prime}$ phosphatase domain of the protein, was reported to affect both the Sacl and $5^{\prime}$-phosphatase activity of synaptojanin 1 (18). However, other homozygous missense mutations, such as p.R839C and p.Y832C, also affecting amino acids located in the $5^{\prime}$-phosphatase domain of the protein, result in typical $\mathrm{PD}$ or $\mathrm{EO}$ atypical parkinsonism, indicating that clinical severity does not depend exclusively on the protein domain affected by the missense mutations (10, 15, this study). Conversely, it could be speculated that mutations leading to premature truncation of the protein in the homozygous or compound heterozygous state, in addition to the p.Y888C mutation, may lead to severe progressive neurodegeneration, whereas homozygous missense variants or compound heterozygous variants with a missense and a premature stop variant in the SYNJ1 gene lead to milder phenotypes associated with parkinsonism and a higher susceptibility to seizures.

In conclusion, this study has extended the mutational and clinical spectrum of SYNJ1 associated with EO typical or atypical parkinsonism and suggests that the screening of this gene should be considered in isolated cases and in patients with a later AO.

\section{DATA AVAILABILITY STATEMENT}

The datasets presented in this study can be found in online repositories. The names of the repository/repositories and accession number(s) can be found at: www.ncbi.nlm.nih.gov/clinvar/ SCV001469064, SCV001469065.

\section{REFERENCES}

1. Halliday G, Lees A, Stern M. Milestones in Parkinson's disease-clinical and pathologic features. Mov Disord. (2011) 26:1015-21. doi: 10.1002/mds.23669

2. Lunati A, Lesage S, Brice A. The genetic landscape of Parkinson's disease. Rev Neurol. (2018) 174:628-43. doi: 10.1016/j.neurol.2018.08.004

3. Cremona O, Nimmakayalu M, Haffner C, Bray-Ward P, Ward DC, De Camilli P. Assignment of SYNJ1 to human chromosome 21q22.2 and Synj12 to the murine homologous region on chromosome 16C3-4 by in situ hybridization. Cytogenet Cell Genet. (2000) 88:89-90. doi: 10.1159/000015493

4. McPherson PS, Czernik AJ, Chilcote TJ, Onofri F, Benfenati F, Greengard $\mathrm{P}$, et al. Interaction of Grb2 via its Src homology 3 domains with synaptic proteins including synapsin I. Proc Natl Acad Sci USA. (1994) 91:6486-90. doi: 10.1073/pnas.91.14.6486

5. McPherson PS, Takei K, Schmid SL, De Camilli P. p145, a major Grb2-binding protein in brain, is co-localized with dynamin in nerve terminals where it undergoes activity-dependent dephosphorylation. J Biol Chem. (1994) 269:30132-9. doi: 10.1016/S0021-9258(18)43787-8

\section{ETHICS STATEMENT}

The studies involving human participants were reviewed and approved by INSERM, CCPPRB du Groupe Hospitalier PitiéSalpêtrière, Paris, France and by the appropriate institutional review boards. The patients/participants provided their written informed consent to participate in this study.

\section{AUTHOR CONTRIBUTIONS}

SL conceived, designed and organized the study, wrote the first draft, reviewed, and critically revised the manuscript. J-CC and $\mathrm{AB}$ conceived the project, reviewed, and critically revised the manuscript. GM, CT, HB, MB, SK, MA, and AS contributed to the execution of the research project and critically revised the manuscript. All authors contributed to the article and approved the submitted version.

\section{FUNDING}

This work was supported by the Fondation de France (FDF; Grant no. 76353), France-Parkinson Association, la Fédération pour la Recherche sur le Cerveau (FRC; Grant no. AFP-FRCR16058DD), and the French Investissements d'avenir program (ANR-10-IAIHU-06). This work was also supported in part by the Intramural Research Program of the National Institute on Aging, National Institutes of Health, Department of Health and Human Services; project number ZO1 AG000949.

\section{ACKNOWLEDGMENTS}

We thank the patients and their families. We thank the DNA and Cell Bank of the ICM for sample preparation.

\section{SUPPLEMENTARY MATERIAL}

The Supplementary Material for this article can be found online at: https://www.frontiersin.org/articles/10.3389/fneur. 2021.648457/full\#supplementary-material
6. Krebs CE, Karkheiran S, Powell JC, Cao M, Makarov V, Darvish H, et al. The Sac1 domain of SYNJ1 identified mutated in a family with early-onset progressive Parkinsonism with generalized seizures. Hum Mutat. (2013) 34:1200-7. doi: 10.1002/humu.22372

7. Quadri M, Fang M, Picillo M, Olgiati S, Breedveld GJ, Graafland J, et al. Mutation in the SYNJ1 gene associated with autosomal recessive, earlyonset Parkinsonism. Hum Mutat. (2013) 34:1208-15. doi: 10.1002/humu. 22373

8. Olgiati S, De Rosa A, Quadri M, Criscuolo C, Breedveld GJ, Picillo M, et al. PARK20 caused by SYNJ1 homozygous Arg258Gln mutation in a new Italian family. Neurogenetics. (2014) 15:183-8. doi: 10.1007/s10048-014-0406-0

9. Drouet V, Lesage S. Synaptojanin 1 mutation in Parkinson's disease brings further insight into the neuropathological mechanisms. Biomed Res Int. (2014) 2014:289728. doi: 10.1155/2014/289728

10. Xie F, Chen S, Cen ZD, Chen Y, Yang DH, Wang HT, et al. A novel homozygous SYNJ1 mutation in two siblings with typical Parkinson's disease. Parkinsonism Relat Disord. (2019) 69:134-7. doi: 10.1016/j.parkreldis.2019.11.001 
11. Kumar S, Yadav N, Pandey S, Muthane UB, Govindappa ST, Abbas MM, et al. Novel and reported variants in Parkinson's disease genes confer high disease burden among Indians. Parkinsonism Relat Disord. (2020) 78:46-52. doi: 10.1016/j.parkreldis.2020.07.014

12. Kirola L, Behari M, Shishir C, Thelma BK. Identification of a novel homozygous mutation Arg459Pro in SYNJ1 gene of an Indian family with autosomal recessive juvenile Parkinsonism. Parkinsonism Relat Disord. (2016) 31:124-8. doi: 10.1016/j.parkreldis.2016.07.014

13. Rauschendorf MA, Jost M, Stock F, Zimmer A, Rösler B, Rijntjes M, et al. Novel compound heterozygous synaptojanin-1 mutation causes l-doparesponsive dystonia-parkinsonism syndrome. Mov Disord. (2017) 32:478-80. doi: $10.1002 / \mathrm{mds} .26876$

14. Ben Romdhan S, Sakka S, Farhat N, Triki S, Dammak M, Mhiri C. A Novel SYNJ1 mutation in a Tunisian Family with juvenile Parkinson's disease associated with epilepsy. J Mol Neurosci. (2018) 66:273-8. doi: 10.1007/s12031-018-1167-2

15. Taghavi S, Chaouni R, Tafakhori A, Azcona LJ, Firouzabadi SG, Omrani $\mathrm{MD}$, et al. A clinical and molecular genetic study of 50 families with autosomal recessive parkinsonism revealed known and novel gene mutations. Mol Neurobiol. (2018) 55:3477-89. doi: 10.1007/s12035-0170535-1

16. Hong D, Cong L, Zhong S, He Y, Xin L, Gao X, et al. Clonazepam improves the symptoms of two siblings with novel variants in the SYNJ1 gene. Parkinsonism Relat Disord. (2019) 62:221-5. doi: 10.1016/j.parkreldis. 2018.11.020

17. Dyment DA, Smith AC, Humphreys P, Schwartzentruber J, Beaulieu CL, FORGE Canada Consortiumet al. Homozygous nonsense mutation in SYNJ1 associated with intractable epilepsy and tau pathology. Neurobiol Aging. (2015) 36:1222.e1-5. doi: 10.1016/j.neurobiolaging.2014. 09.005

18. Hardies K, Cai Y, Jardel C, Jansen AC, Cao M, May P, et al. Loss of SYNJ1 dual phosphatase activity leads to early onset refractory seizures and progressive neurological decline. Brain. (2016) 139:2420-30. doi: 10.1093/brain/ aww180

19. Al Zaabi N, Al Menhali N, Al-Jasmi F. SYNJ1 gene associated with neonatal onset of neurodegenerative disorder and intractable seizure. Mol Genet Genomic Med. (2018) 6:109-13. doi: 10.1002/mgg3.341
20. Samanta D, Arya K. Electroclinical findings of SYNJ1 epileptic encephalopathy. J Pediatr Neurosci. (2020) 15:29-33.

21. Hughes AJ, Daniel SE, Kilford L, Lees AJ. Accuracy of clinical diagnosis of idiopathic Parkinson's disease: a clinico-pathological study of 100 cases. $J$ Neurol Neurosurg Psychiatry. (1992) 55:181-4. doi: 10.1136/jnnp.55.3.181

22. Bouhouche A, Tesson C, Regragui W, Rahmani M, Drouet V, Tibar H, et al. Mutation analysis of consanguineous Moroccan patients with Parkinson's disease combining microarray and gene panel. Front Neurol. (2017) 8:567. doi: 10.3389/fneur.2017.00567

23. Lesage S, Drouet V, Majounie E, Deramecourt V, Jacoupy $M$, Nicolas A, et al. Loss of VPS13C function in autosomal recessive parkinsonism causes mitochondrial dysfunction and increases PINK1/Parkin-dependent mitophagy. Am J Hum Genet. (2016) 98:500-13. doi: 10.1016/j.ajhg.2016.01.014

24. Picillo M, Ranieri A, Orefice G, Bonifati V, Barone P. Clinical progression of SYNJ1-related early onset atypical parkinsonism: 3year follow-up of the original Italian family. J Neurol. (2014) 261:823-4. doi: 10.1007/s00415-014-7270-6

25. Upreti C, Otero R, Partida C, Skinner F, Thakker R, Pacheco LF, et al. Altered neurotransmitter release, vesicle recycling and presynaptic structure in the pilocarpine model of temporal lobe epilepsy. Brain. (2012) 135:869-85. doi: 10.1093/brain/awr341

26. McPherson PS, Garcia EP, Slepnev VI, David C, Zhang X, Grabs D, et al. A presynaptic inositol-5-phosphatase. Nature. (1996) 379:353-7. doi: $10.1038 / 379353 \mathrm{a} 0$

Conflict of Interest: The authors declare that the research was conducted in the absence of any commercial or financial relationships that could be construed as a potential conflict of interest.

Copyright (C) 2021 Lesage, Mangone, Tesson, Bertrand, Benmahdjoub, Kesraoui, Arezki, Singleton, Corvol and Brice. This is an open-access article distributed under the terms of the Creative Commons Attribution License (CC BY). The use, distribution or reproduction in other forums is permitted, provided the original author(s) and the copyright owner(s) are credited and that the original publication in this journal is cited, in accordance with accepted academic practice. No use, distribution or reproduction is permitted which does not comply with these terms. 